\title{
The Rhetoric of Madness in Kathy Acker's Don Quixote
}

\author{
Claudia Cao \\ Department of Philology, Literature and Linguistics, University of Cagliari, Italy
}

Received: 19-05-2017

Accepted: 05-07-2017

Published: 31-07-2017

doi:10.7575/aiac.ijclts.v.5n.3p.72

URL: http://dx.doi.org/10.7575/aiac.ijclts.v.5n.3p.72

\begin{abstract}
This essay examines the rhetorical experimentation of Don Quixote by Kathy Acker, starting from a theoretical concept central in the author's thought: her search for a "language of the body". A brief introduction to Kathy Acker's plagiaristic poetics frames her narrative strategies between postmodern rewriting and pastiche. It shows the way in which her Don Quixote transposes the representative scheme of the chivalric quest into the contemporary value system with the aim of questioning Cervantes' text as one of the canonical works of the Western literary tradition. The following section deepens three focal concepts of Acker's theoretical works - body, madness, and norm illuminating the connections between her rhetorical experimentation and the works by Luce Irigaray and Judith Butler. Finally, the paper will demonstrate how these concepts in Acker's rewriting of Don Quixote are strictly related to paradox, which she uses in order to actualize a "language of the body": in the passage from the former novel to the postmodern work, madness has become the device which, from the semantic level to the rhetorical one, expresses Acker's idea of language of the body, as an alternative and in contrast to the canonical language of the logos.
\end{abstract}

Keywords: Rewriting, Pastiche, Madness, Feminism, Luce Irigaray, Judith Butler

\section{Introduction}

Before analyzing the ways in which Kathy Acker's Don Quixote (1986) elaborates its peculiar relationship among body, discourse and madness, it is necessary to focus on some theoretical and conceptual premises of Acker's literary and critical production ${ }^{1}$.

In line with her plagiaristic poetics ${ }^{2}$, this work establishes a complex web of links with its Spanish predecessor. Indeed, Cervantes' text is not the only illustrious ancestor evoked by this work: among the references identified in Acker's novel are those to Tomasi di Lampedusa's The Leopard, to Beckett's Waiting for Godot, to Dante's Comedy, and Carmen VIII by Catullus, as well as to philosophical texts such as those by Hobbes, Foucault, Althusser, and Sylvère, mixed with pornographic fragments or pieces of American history ${ }^{3}$.

As inferred from these references to such disparate text types, literary genre plays a key role in understanding how the the body of the text is revisited in Acker's writing. The juxtaposition of fragments of various works is one of the means through which genre is questioned: considered a cornerstone of the interpretation of the literary text and the canonical hierarchy between high and low culture, genre is the filter that Acker rejects as limiting both interpretation and literary creation as well as representing a chain binding the artist to the tradition ${ }^{4}$.

Given the strict relationship among language-body-identity in Acker's production - deeply influenced by Foucauldian thought - freeing her texts from these chains and allowing readers access to her literary works without these constraints is a fundamental step in her rethinking of the relationship between identity and power. If the construction of the self and, consequently, of sexual identity, depends on the dominant discourse, the deconstruction of the norms given is possible only by questioning these dividing lines on which the construction of the individual is based, as much as the literary discourse itself is.

This article aims to illustrate the way in which the different textual levels of Don Quixote act together in achieving the deconstruction of conventional paradigms in the discursive representation of identity. The text elaborated by Acker in relation to the Cervantes' original novel cannot be entirely encompassed by the categories of postmodern rewriting (Doležel 1999) or pastiche (Genette 1997). Acker's work does share certain strategies with postmodern rewritings such as the transposition of a representative scheme (that of the chivalric quest) into the contemporary world and into its different value system. With the pastiche it has in common its allusive and ironic function deriving from the combination and juxtaposition of quotes and fragments of various origins. This bond established with the original text by Cervantes will be shown on the diegetic and formal level, but mostly on the thematic and figural levels: both the way in which Acker subverts the structure of Don Quixote by reinterpreting it, and the way in which she re-functionalizes the theme of madness. Finally, this article will prove how the rhetorical level of Acker's novel reflects the intent to question the existing paradigms of identity in order to unmask, behind the clichés and stereotypes, the limited and limiting concept of the dialectic between men and women, me-not me. 


\section{Bodies and norm}

In Bodies of Work Kathy Acker elucidates the close link between norm, sexual identity, and access to the sphere of the intelligible. This theoretical writing is essential for understanding the choice of Cervantes' Don Quixote as the main intertext of her novel.

The decision to give a woman a typical male role - the knight - in fact recalls the author's desire and need, since childhood, to take refuge in the literary world: for example, the desire to become a pirate ("When I was a child, I knew that the separation between me and piracy had something to do with being a girl. With gender. With being in a dead world. So gender had something to do with death" [Bodies of Work 160]) $)^{5}$.

The awareness of the impossibility of escape from the hierarchical dominance of the male and of the embodiment of a different role than that assigned to women is one of the prime reasons for the splits between reality and dream, reality and fictional world, that characterize a large part of Acker's production. Patriarchy and death are closely interrelated in Acker's vision and are in antithesis to the correspondence between literature and vitality, often created in her works:

Barely born, I was dead. The world of my parents [...], the world in which I had to wear white gloves and panty girdles even though I was skinny, was a dead world. Whereas pirates lived in the living world because pirates had fun. Since pirates lived in my books, I ran into the world of books, the only living world I, a girl, could find. I never left that world. (Acker Bodies of Work 159) ${ }^{6}$

The awareness of the arbitrariness of the concept of essential identity and of the existence of a pre-discursive sex implies the need for a new language capable of expressing the "in-between condition"7. In her vision, gender is conceived not only as a criterion for the distinction and the subjugation of bodies, but also as a producer of the rules by which the body gains a life and a social recognition. Gender endures only thanks to its constant repetition: to shake and to dismantle the linguistic political and sociological categories means, therefore, undoing the same epistemological assumptions that underlie the current sexual positions and the heterosexual paradigm. If the discourse has built the frames of intelligibility within which lies the identity, to change the social models - exogamous and heterosexual - also means operating on the level of discourse for the purpose of the recognition and the inclusion of all those identities left outside the boundaries set by the norm ${ }^{8}$.

The vision of the body in Acker'as rethinking of these paradigms is not founded on a static conception. She views the body as the process of becoming that "exceed[s] the norm, rework[s] the norm, and expose[s] realities to which we thought we were confined as open to transformation" (Butler, Undoing Gender, 217). Acker, in the attempt to catch the body in all its materiality, and to escape the language of the fathers, elaborates a writing which is an actualization of the "language of the body", the only language, in her opinion, capable of dealing with the corporeal, viewed as what "is constantly changing and unpredictably [...] chaotic" (Bodies of Work 147), thus where "meaning and essence no longer oppose each other" (Bodies of Work 149).

The inextricable link between the materiality of the body and the processes of signification is therefore the focus of Acker's rhetorical experimentation. Through the performative function of her hybrid texts, Acker aims at materializing unforeseen bodies.

\section{Don Quixote}

Excluding the name of the main character and the allusion in the first part of the novel to some episodes of Cervantes' work, Don Quixote is completely freed from the source text ${ }^{10}$ : the processes put in place in the review of the hypotext predominantly involve the formal and thematic level and refer only partially to the plot. From the beginning, we can observe the source text re-reading and modernization process:

When she was finally crazy because she was about to have an abortion, she conceived of the most insane idea that any woman can think of. Which is to love. How can a woman love? By loving someone other than herself. [...] By loving another person, she would right every manner of political, social, and individual wrong: she would put herself in those situations so perilous the glory of her name would resound. (Don Quixote 9)

As in the original text, and as in much chivalric literature, the loving quest is the narrative starting point. The object of search, however, ceases to be the usual desire object - expression that Acker questions in the following pages - and becomes the meaning of love tout court:

'Why can't I just love?

'Because every verb to be realized needs its object. Otherwise, having nothing to see, it can't see herself or be. Since love is sympathy or communication, I need an object which is both subject and object: to love, I must love a soul. Can a soul exist without a body? Is physical separate from mental? (Don Quixote 10)

From this moment on, the path of the wandering knight - initially unnamed - will focus on finding answers to those questions central to the Western philosophical thought; she will be guided to questioning the exclusively heterosexual and exogamous concept of love and its reformulation in a broader sense. The mind-body Platonic dichotomy is not only seen at the origin of the matter-logos binarism, and at the consequent hegemony of the mind over the body - as suggested in Irigaray's feminist interpretation of Timaeus ${ }^{11}$ - but it is also designed as a starting point of the heterosexual paradigm ${ }^{12}$. 
It is no coincidence that the episode in the opening scene of Quixote is an abortion: opposing this first gender stereotype, which sees the woman as pure matter, closely related to the concept of mother and to the reproductive function, is undoubtedly one of the major goals of the opening scene:

I had an abortion because I refused normalcy which is the capitulation to social control. To letting our political leaders locate our identities in the social. In normal good love: 'It's sick to love someone beyond rationality, beyond a return (I love you you love me). Real love is sick. I could love death [...] I want love. The love I can only dream about or read in books. I'll make the world into this love. (Don Quixote 17-18)

The decision to confer this topical position to the theme of abortion is therefore confirmed in the first part of the novel, in which the narrator reveals the main target of her writing: the contradiction between the conventional concept of love and the daily life, where the relationship between man and woman is affected by hegemonic, sexist logic. The main accomplices pointed out by Acker on several occasions as responsible for this contradiction are two founding texts of the Western culture: on the one hand the Bible - which she defines "The Storehouse of Language" (Don Quixote 27) and on the other hand the classics - provocatively called "male texts" (Don Quixote 39). After the questions asked at the beginning, the search for answers is carried out by this new Quixote in three stages aimed at unmasking the main institutions and agencies responsible for the establishment and repetition of the norms: from the classical and modern texts in the canon of Western philosophical and poetic tradition, up to American history and contemporary politics. In the first and shortest part, entitled "The Beginning of the Night", which is more anchored to the source text, the protagonist acquires existence through baptism and experiences the first sorties as a knight, after choosing a dog named Saint Simeon as her Sancho Panza and the chair of the hospital where she goes for the abortion as her Rocinante; in the second part, entitled "Other Texts", the protagonist questions the male texts in search of a language of her own ${ }^{13}$; finally, the third one, entitled - symmetrically to the first section - "The End of the Night", shows the "return" of the knight to Spain ${ }^{14}$.

Contrary to what the titles of the first and the last part suggest, Don Quixote firstly initiates the operation of its rejection of narrative conventions through the negation of the structure of classical novels, aimed at the denouement of the plot: as the title of one of the last chapters reminds the reader - "the Last Adventure: Until this Book will Begin Again" (Don Quixote 175) - Don Quixote is the anti-novel par excellence, "in which the events take place on a self-spiral and do not come to any conclusion " (Ceserani 177$)^{15}$. In addition to the fragmentation and heterogeneity of the sections already mentioned, the main ingredients of this narration are the wildly multiperspective vision and extreme polyphony resulting from the lability of the identity of the characters; the heteroglossic narrative, due both to the choice of this "obsessively parodic and encyclopaedic metanarrator" (Ceserani 177) and to the constant mingling of high culture and low culture; and the space-time disorientation, which prevents the reader from fully understanding the changes in place and time in the novel. The absence of a sole storyteller - given by the initial anonymity of the protagonist, and by the continuous changes of the narrator - is undoubtedly a central aspect in the process of deconstruction of the dialectic benot be from which the wandering of the protagonist starts.

The choice of Don Quixote and the role of the knight as a key figure is particularly interesting, not only for the sexual ambiguity of the main character ${ }^{16}$, but also as a starting point for a process of "re-semantization" of some episodes of the source text, in particular the act of the baptism. The topos of baptism acquires a double meaning in relation to this new Quixote: on the one hand, it represents the first step for access to the language, from which the narrator as a woman is excluded, and on the other hand, the baptism recalls the performative role of the name which establishes gender, and from which depends the recognition of the identity of the body (Bodies that Matter 72). Regarding the first meaning, baptism is the act through which the protagonist accesses the sphere of the intelligible and therefore existence. Before that moment, at the request of the receptionist of the hospital, the protagonist answers that she is not able to provide any identity documents and that she is still waiting to acquire one:

I can't give you the papers because I don't have an identity yet. I didn't go to Oxford or Cambridge and I'm not English. This's why your law says I have to stay in this inn overnight. As soon as you dub me a knight - by tomorrow morning - and I have a name, I'll be able to give you my papers.» (Don Quixote 11)

Baptism and access to the word are in fact converging in the author's thought, who, referring to Butler, observes:

$[\ldots]$ as a girl I was outside the world. I wasn't. There was no entry for me into language. As a receptacle, as a womb, as Butler argues, I could be entered, but I could not enter, and so I could nether have nor make meaning in the world. [...] I could be entered, but I could not enter, and so I could neither have nor make meaning in the world. [...] Though I couldn't be named, everyone was naming me. (Bodies of Work 161)

The second function of the baptism refers to the Lacanian assumption «C'est par l'homme fait que nomination subsister les objets dans une certaine consistence» (202) which suggests that the integrity of the body is based firstly on the names, symbols of the dominance of the paternal law. Nomination means being imprinted in patriarchal law and referring to the body - being shaped in accordance with the law. The protagonist's act of re-nomination, selfnomination, represents the first revision of these assumptions. As the other textual strategies adopted by the entire narrative to reject and overthrow the law of the fathers, this act of self-determination implies the rejection of the paternal lineage and the morphological coherence conferred by name: the choice of a name that breaks the norm is not only a starting point for this disintegration of the conventional version of the bodily integrity but especially for the rehabilitation of unconventional versions of body materiality (Don Quixote 10: "By taking on such a name which, being long, is male, she would be able to become a female-male or a night-knight"). The fact that the name acquired by the 
protagonist is also fixed in the collective imagination as designating the Cervantes character is a further step forward in the definition of the inclusive logic that animates Acker's writing.

If we analyze the intertextual links at the semantic level, it is clear that the two themes of the ambiguous identity and the madness create an intersection between Acker's work and Cervantes' novel, where the metafictional play, the constant overlap between reality and invention, corroborates the ontological ambiguity of the story. The theme of madness has been subjected to a process of re-functionalization in the passage from the source text to Acker's work: first of all, as a means of overcoming the exclusive and binary logic to which ordinary language submits - in accordance with the principle of non-contradiction on which Western thought is based - the madness lies at the origin of the paradoxes that Acker's narration constantly produces; moreover, this mad knight as the central figure of the work is an emblem of those who are excluded from society ${ }^{17}$; finally, in accordance with the fool's traditional role as prophet in Western literary and theatrical production, the madness of the protagonist aims to unmask lies and contradictions of hegemonic discourse behind fixed stereotypes and clichés imposed by institutions ${ }^{18}$.

The institutions which the protagonist faces are the representative types of contemporary politics (the Progressive, the leftist, the Feminist, repeatedly unheard or silenced ${ }^{19}$ ), allegories of power (Fame, State Affairs ${ }^{20}$, iconic figures of the church, education, family, constantly drawn as claustrophobic and despotic institutions ${ }^{21)}$. In other cases, the protagonist's targets are the different forms of discourse of the Western tradition: history, always defined as propaganda ${ }^{22}$; the language of literary criticism, viewed as the art cage because it defines the text within rigid schemes; and the Bible, which has established the female unnatural stereotype of chastity ${ }^{23}$, and which first contributed to the fixing of the image of the woman in Western culture as a scapegoat, as the cause of evil and human suffering ${ }^{24}$.

Madness in the passage from the hypotext to the contemporary work has therefore become a means through which discursive strategies unmask the responsible agencies for the fixing of a rigid conception of identity, which necessarily implicates a dialectical relationship with otherness.

\section{The rhetoric of madness}

Before returning to the link between madness and paradox in Acker's writing, it is necessary to refer to the background behind Acker's formal experimentation: the search for that "language of the body" which she conceives in opposition to "the language of the logos" (Bodies of Work, 89). Her creation of a language of the body, defined by Acker as the "language of flux, of material, of That Which Must Die [...] "Nonpatriarchal Language"” (Bodies of Work 89), especially embraces the structures of the discourse. It is therefore interesting to investigate the way in which her experimentalism actualizes the overcoming of binarism and the structures of the conventional discourse in order to reproduce, by means of writing, the labyrinths of the identity and the body, the actual and the existent in their contradictions, exposing the inadequacy of language to express the intensity of body experiences and, consequently, the inability to enclose the body, the natural, into the rigid cages of logos ${ }^{25}$. The language of the body, developed by Acker to grasp the ever-changing body in all its contradictions, can only be expressed by structures that reflect the materiality "controlled by change and by chance" (Acker, Bodies of Work, 149), as the author repeatedly emphasizes.

In view of these objectives we can notice the extensive use of figures of repetition, often repetition with difference, until the open contradiction and paradox. The repetition in this regard assumes different functions. Firstly, it addresses the destabilization of the principle of non-contradiction if adopted within false syllogisms:

The Prince doesn't have any morals. Why? Because morals are part and parcel of a government which runs partly by means of the so-called 'have-nots' or bourgeoisie's cover-up, (via 'Culture'), of the 'haves' total control. Morality and 'Culture' are similar tools. The only culture that even causes trouble is amoral. The Prince isn't moral: he doesn't give a shit about anybody but himself. The Prince wouldn't die for anyone, whereas Our President will always die for everybody while he's garnering in their cash (Don Quixote 21)

In cases like this, in fact, the widespread use of etymological figures and polyptoton contributes to the desecralization of two key concepts, that is, morality and culture, gradually unmasking hypocrisy hidden behind these labels: the parallelism between the amorality of the Prince and morality of the President, indeed, ends with an unexpected imbalance in favor of the former over the latter ${ }^{26}$.

A similar function is attributed to frequent anadiplosis such as "These aren't the marks of heterosexual love, but of Catholics. Catholics, since they're celibate, throw stones" (Don Quixote 31). Here the repetition of the reference to the Catholics, linked to violence and heterosexual love in a kind of syllogism - as the use of "since" suggests - combined with similar allusions throughout the text, inevitably creates a link between the repression of Catholicism and violence, undermining another bastion of Western morality. In other cases the element stressed is a cliché of women or a question isolated in the speech, which invited the reader to pause on that image or on the question left without answer. An example in this regard is the repetition with variation of the phrase "the girls cross their legs and laugh" (Don Quixote 53 ) and "the other girl lay on her red bed and crossed her legs" (Don Quixote 53) or the question, "How, exactly, does my body feel pleasure?:" (Don Quixote 55), “How, exactly, does my body feel pleasure?" (Don Quixote 56) ${ }^{27}$, in which the lack of answer emphasizes the impossibility of a full rational control over human experiences and the untruthfulness of the control of the logos on the matter.

The destabilizing play of repetitions and parallels on the level of the signifier is intensified in Acker's writing by the emblematic use of the paronomasy between knight/night, which plays a large part in the narrative ${ }^{28}$. As suggested by Giampaolo Sasso, intralinguistic devices like this one, in contrast to the stability of the bond signifier-signified, allow readers to create a more fluid organization of the discourse that does not meet the conventionally valid criteria for 
stability (8). The deconstruction of meaning through the use of these almost synonymic terms creates for the author new associative correspondences not covered by the standard grammar rule: it not only refers to the descent of this knight into the underworld, enveloped in the darkness of the city, but it also flows into nonsense, corroborating the effects of the many paradoxes:

Therefore, night, you always need love with desperate animalism and you can't actually love, that is clearly perceive your love's recipient.

'Night: Where are your eyes?' (Don Quixote 196)

In cases like this one, the function of the constant paronomasy between the terms knight/night and eyes/I's is also accentuated by the combination of the two terms night-eyes that recall in absentia the second element, emphasized by the function of allusive suspension in which the question is left, again without answer.

The predominant expressive form between the rhetorical strategies of Acker, is, however, the paradox, the peculiar composition of which McBride has examined:

Acker takes paradox to a new level. Traditionally, paradox has implied two opposing, mutually exclusive concepts that appear, after some contemplation, to be naturally, reasonably true. Acker's paradoxes are indeed opposing, mutually exclusive concepts, but they do not appear true; they are simply stated and are [...] therefore implied, or at least inferred, as true. (McBride 350)

As McBride points out shortly after, the processes from which Acker's paradoxes originate are two: fission, which splits a concept into two opposing extremes declaring that both statements correspond to the truth, and fusion, which fuses together two apparently incongruent concepts. The effect is once again to destabilize the reader and to undermine the rationalist approach. Issues related to the sphere of existence, identity, appearance, love, money, and all the values of contemporary society are continually challenged by the narrator's paradoxes.

As for previous rhetorical strategies taken into consideration, it is not possible here to highlight the large number of paradoxes proposed by Acker's text. However, I will focus on some of them to illustrate how the targeted objects of the protagonist's madness are once again some of the pillars of Western thought, among which the idea of an absolute, organic and coherent reality:

The first kind of time, lines one through four, is linear time. The first main verb is is, an is which isn't Platonic. This common is leads to the first person subjunctives, fear and hinder, as well as the is' subject noun, fear. This kind of time or the world makes human fear.

Common time's other or enemy is death. Is is bounded by death. So the other of is is is be without in the present tense. (Don Quixote 50)

This quote refers to the paraphrase of Carmen VIII by Catullus proposed by the narrator, whose central theme is precisely the contrast between past and present, the split between heart and reason, and the splitting of the self. In this fission process, the relationship between language and identity, with attention for the use of tenses and the various verbal forms of existence, becomes central. It is the core of the entire paraphrase, aimed at revealing the performative function of the discourse in the actualization of the reality:

the past controls the present [...] By repeating the past, I'm molding and transforming it, an impossible act. [...] My present is negative. The present becomes imaginary: The future of amabitur and the subjunctive at the beginning of the poem?: (Don Quixote 47-48)

The subjunctive, as the mode of the possibility, is defined by the narrator as the mode of change, of mobility which "grammatically reflect[s] this new model of common time: change is time" (Don Quixote 51) in contrast to the indicative that she calls "absolute" (Don Quixote 51).

Even the paradoxes cooperate in the process of insubordination to the law of the fathers represented in its various agencies, starting from her family:

I'm always cold in the apartment cause no one hugs me. They don't hug me cause I'm unlike other people: I'm neither male or female. My nurse likes my sisters and brother unlike me, because they, unlike me, 're normal.

I'm weird. I love the river because it isn't human and I'm not human. (Don Quixote 142)

Love in all its forms is the object of the search of the character, which, in these scenes of family life, highlights once again the illusory image created by the Western culture:

"I'm not your mother. Don't speak that way to your mother."

"How can I speak to you?"

"Children have no right to ask questions. So until you learn to be quiet, keep your fat trap shut." (Don Quixote 142)

The silence to which the protagonist is reduced in these contradictory and paradoxical scenes of her childhood, as well as being emblematic of the situation of exclusion, focuses also on the state of marginalization denounced from the beginning of the work for not being a normal girl, according to the norm.

The fusion processes are the ones that mainly help to undermine the concept of love, in particular through the juxtaposition of elements concerning the antonymic semantic sphere of hatred, violence and destruction: "in order to 
make her part of a community Don Quixote's friends dragged her toward her bed, which was a mattress on the floor, [...] They didn't need to care for or love her. [...] Her friends, aghast at femininity, determined to burn it out." (Don Quixote 16-17) and then "“A teacher at night told us to go downstairs. There he flogged us hard. The sound of floggings is now love to me"' (Don Quixote 13).

Another target object of Acker's paradoxes is the crystallized expressions, in particular, expressions such as "love's object" or "desire's object". Used in this alienating context, they emphasize the performative role played in the construction of paradigms in force and how they have contributed to the naturalization of conventional dialectic between the sexes: "Just as love's object is the appearance of love; so the physical realm is the appearance of the godly: the mind is the body" (Don Quixote 10); and then "II'm your desire's object, dog, because I can't be the subject. Because I can't be the subject: What you name 'love', I name 'nothingness'. I won't not be: I'll perceive and I'll speak." (Don Quixote 28).

To fully understand the meaning of the reuse of these expressions crystallized into common use, it should be taken into account that these are acts of appropriation of dominant culture aimed at redefining the terms of that domination: this redefinition, indeed, as observed by Butler (1993), is a kind of action that repeats in order to remake. Their reuse is therefore in opposition to the act of citation that allows the survival and transmission of the norms: Acker's inclusive logic does not repeat the same dynamics of foreclosure of the hegemonic discourses, but incorporates and assimilates the language of the fathers in order to overcome existing frameworks.

\section{References}

Acker, K. (1986). Don Quixote, which was a dream. London: Paladin.

Acker, K. (1992). Kathy Acker interviewed by Rebecca Deaton. Textual Practice, 6.1, 271-282.

Acker, K. (1997). Bodies of Work. London: Serpent's tail.

Butler, J. (2004). Undoing Gender. Now York-London: Routledge.

Butler, J. (1993). Bodies that Matter. On the Discursive Limits of "Sex". New York-London: Routledge.

Cao, C. (2012). Per una poetica del plagio. Il caso di Kathy Acker. Between 2.3, 1-23.

Cervantes Saavedra, M. (2009). El Ingenioso Hidalgo Don Quijote de la Mancha. Trans. F. Carlesi Don Chisciotte della Mancia. Milano: Mondadori.

Ceserani, R. (1997). Raccontare il postmoderno. Torino: Boringhieri.

Colby, G. (2016). Kathy Acker: Writing the Impossible. Edimburgh: Edinburgh University Press.

Doležel, L. (1999). Heterocosmica. Fiction and Possible Worlds (1998). Trans. M. Botto. Heterocosmica. Fiction e mondi possibili. Milano: Bompiani.

Foucault, M. (1996). Dits et écrits (1994), Transl. G. Costa. Archivio Foucault. Interventi, colloqui, interviste. 1. 19611970. Follia, scrittura, discorso. Ed. Judith Revel, Milano: Feltrinelli.

Garrigós, C. (2009). Kathy Acker's Spanish Connection: Plagiarism, Madness and Love in Don Quixote. In P. Mackay, K. Nicol (eds. and introd.), Kathy Acker and Transnationalism (pp. 115-132). Newcastle upon Tyne: Cambridge Scholars.

Genette, G. (1997). Palimpsestes. La littérature au second degré (1982). Trans. R. Novità. Palinsesti. La letteratura al secondo grado. Torino: Einaudi.

Huppatz, D. J. (2007). Corporeal Poetics: Kathy Acker's Writing. In Louis Armand (ed.), Contemporary Poetics (pp. 11-125). Evanston: Northwestern University Press.

Irigaray L. (1993). Ethique de la différence sexuelle. Trans. C. Burke - G. C. Gill. An Ethics of Sexual Difference. New York: Cornell University Press.

Irigaray L. (1985). Speculum de l'autre femme. Trans. G. C. Gill. Speculum of the Other Woman. New York: Cornell University Press.

Lacan, J. (1978). Le séminaire. Livre II. Le moi dans la théorie et dans la technique de la psychanalyse. Paris: Seuil.

McBride, S. (1999). Un-Reason and Ex-Centric Text: Methods of Madness in Kathy Acker's Great Expectations. Critique 40.4, 342-354.

McCaffery, L. (1991). Interview with Kathy Acker. Mississippi Review 20-1/2, 83-97.

McCaffery, L. (2010). Kathy Acker: Always Missing-A Plagiarized Tribute. Critique: Studies in Contemporary Fiction, 51.2, 104-111.

McHale, B. (1987). Postmodernist Fiction. London-New York: Routledge.

Schlichter, A. (2003). Critical Madness, Enunciative Excess: The Figure of the Madwoman in Postmodern Feminist Texts. Cultural Studies $\leftrightarrow$ Critical Methodologies, 3. 3, 308-329.

Schlichter, A. (2007). "I can't get sexual genders straight": Kathy Acker's writing of bodies and pleasures. Postmodern Culture, 17. 2, http://pmc.iath.virginia.edu/text-only/issue.107/17.2schlichter.txt. 
Notes

Note 1. The most complete collection of essays by Kathy Acker on issues of authorship and gender is Bodies of Work. Among her interviews about these topics see McCaffery 1991, Acker 1992. On madness in Don Quixote see Garrigós 2009, McBride 1999.

Note 2. For an overview of the author's poetics and its plagiaristic practices see Cao 2012, Colby 2016, McCaffery 2010 .

Note 3. Among the quotations: Catullus (Don Quixote 47-49), Waiting for Godot (83), The Leopard (59-64), Husserl, Deleuze, Guattari, Lacan, Althusser, Foucault, Sylvère, Baudrillard (54-55), Paradise Lost (83), Sartre (86), Sade's Augustine de Villebranche (133-141), the Oedipus's myth (147-150).

Note 4. See McHale, 166-171.

Note 5. The parallelism between normality and death, normality and alienation in Don Quixote is constant and creates a series of matches with another symmetry, especially that between heterosexual love and death, highlighting the author's opposition to the idea of union as conventionally understood, as normally dictated and imposed by the main texts of the Western tradition from the Bible and classical texts and modern (see Don Quixote 28: “As long as you men cling to your identity of power-monger or of Jesus Christ, as long as you cling to a dualistic reality which is reality molded by power, women will not exist with you. [...] When you love us, you hate us because we have to deny you. Why? [...] your love has to drive you to suicide"; Don Quixote 34: “[...] Don Quixote knew she was no longer a knight but shit and dead, that is, normal.").

Note 6. The term “viability” (Butler Undoing Gender) helps to understand the double aim of Acker's writing, where the performativity of the discourse is basic. The term, in fact, referring to the same concepts of vitality and feasibility, becomes a starting point for understanding the interpenetration of the world, discourse and body central in Acker's thought (see Acker, Bodies of Work, 62: "For the poet, the world is word. Words. Not that precisely. Precisely: the world and words fuck each other").

Note 7. These territories "in between" are the areas that Butler (1993) has called "unlivable" and "uninhabitable" in the social life but densely populated by those who do not have the status of subjects. (See Don Quixote 201: "It is true that women are never men. Even a women who has the soul of a pirate, at least pirate morals, even a woman who prefers loneliness to the bickerings and constraints of heterosexual marriage, even such a woman who is a freak in our society needs a home. 'Even freaks need homes, countries, language, communication."'). On bodies in Kathy Acker's production see also Schlichter 2007.

Note 8. See Butler Bodies that Matter.

Note 9. See Acker Bodies of Work 147: “[...] a language of the body [...] rejects ordinary language and itself constitutes a language, a method for understanding and controlling the physical which in this case is also the self'. The centrality of the body is confirmed in Don Quixote, where she writes: "[...] the body is the first ground of knowledge $[\ldots]$ ".. (168).

Note 10. The only episodes of the hypotext which are explicitly recalled are the choice of her "Rocinante", the moment in which she receives the knight armor, the meeting with "Sancho Panza" (a dog called Saint Simeon) and the episode of the farmer who punishes his boy (see Don Quixote 14-15 "the first adventure"). After the first fifteen pages, even if the titles of individual chapters refer to the adventures of Quixote, reference to the source text becomes purely allusive. What remains is a framework parallel to Cervantes' text.

Note 11. See Irigaray Speculum and Ethics of Sexual Difference.

Note 12 . We can remember that the etymological connection between matter-mother-matrix elaborated by Butler refers to the way in which the Platonic thought is at the origin of these dichotomies referring to sexual positions.

Note 13. See Don Quixote 39: "Being dead, Don Quixote could no longer speak. Being born into and part of a male world, she had no speech of her own. All she could do was read male texts which weren't hers".

Note 14. See Don Quixote 201: "But being vacant Don Quixote looked vacantly at the bourgeoisie. She had no idea where she was. Where in hell she was. She had never been in Spain".

Note 15. Translation is mine.

Note 16. See Don Quixote 29: "She had to become a knight, for she could only solve this problem only by becoming partly a male.

Note 17. On madness as exclusion from society, see Foucault 1996.

Note 18. See Foucault 1996, Schlichter 2003.

Note 19. See Don Quixote 18-19.

Note 20. See Don Quixote 120.

Note 21. See See Don Quixote 116, where the family is defined "a prison" and the daughter "property".

Note 22. See Don Quixote 101-123.

Note 23. One of the repeated expressions is "Virgin mother" (see Don Quixote 152). 
Note 24. See Don Quixote 27: "Traditionally, the human world has been divided into men and women. Women're the cause of human suffering. [...] In Our Bible [...] we tried to tell women who they are: The-Loving-Mother-Who-HasNo-Sex-So-Her-Sex-Isn't-A-Crab [...]".

Note 25. For a description of the ten elements that characterize the language of the body, see Bodies of Work 91-92.

Note 26. At the end of the book the reference is more explicit: "What you call history and culture is the denial of our flowing blood" and a little after "because it isn't true that animal life is over, / because we are not worthless dogs, / because we are not slaves, oh landlords, [...] because your human history which is the history of slavery is / not our history, / because your culture is slavery" (Don Quixote 198). In this case the use of the new line accentuates the parallels between the human condition, animal and slavery, created by means of anaphora and epanadyplosis.

Note 27. This quotation highlights how punctuation is another means through which Acker's writing is opposed to the conventions of discourse through the infringement of the rule, as shown by her use of quotation marks and colons.

Note 28. The importance of paronomasia in Acker's language of the body is accentuated by other examples such as I/eye, We/oui (Don Quixote 199), which, although present to a lesser extent, help to emphasize through the screeching of the two semantic elements the role of this violent combination as expression of the contradictions and fluidity of what concerns the human. In a case such as the I/eye there is a clear allusion to the function that feminism has given to the relationship between the two terms, in reference to the dialectic subject-object theorized by Hegel, explicit target of Acker's writing. In other cases - such as "pubic/public" (Don Quixote 120) - the function of this combination is purely ironic and irreverent. 